\section{Leucas mollissima, a Source of Bio- active Compounds with Antimalarial and Antimycobacterium Activities}

\author{
Ashish A. Chinchansure ${ }^{1}$, Manisha Arkile ${ }^{2}$, Anurag Shukla ${ }^{3}$, \\ Dhanasekaran Shanmugam ${ }^{3}$, Dhiman Sarkar ${ }^{2}$, Swati P. Joshi ${ }^{1}$ \\ ${ }^{1}$ Division of Organic Chemistry, CSIR-National Chemical Laboratory, \\ Pune, India \\ ${ }^{2}$ Combi-Chem Bio-Resource Centre, CSIR-National Chemical \\ Laboratory, Pune, India \\ ${ }^{3}$ Biochemical Sciences Division, CSIR-National Chemical Laboratory, \\ Pune, India
}

\section{Abstract \\ $\nabla$}

A phytochemical investigation of the acetone extract from the aerial parts of Leucas mollissima afforded one new (-)epi-marmelo lactone, $(2 S, 4 R, 6 S)$-2,6-dimethyl-6 hydroxy-7-ene-4-olide (1), along with five known compounds, schensianol A (2), vanillin (3), $\beta$-hydroxy propiovanillone (4), lanost-9(11),25-diene$3 \beta, 24 \beta$-diol (5), and lanost-9(11),23E(24)-diene-3 $\beta, 25$-diol (6). Similarly, an investigation of the methanol extract of the aerial parts of $L$. mollissima resulted in the isolation of three known compounds, (+)-syringaresinol (7), anisofolin A (8), and apigenin 7-0- $\beta$-D(-6"-p-E-coumaroyl)-glucoside (9). Structure elucidation of the isolated compounds was carried out using detailed analysis of 1D and 2D nuclear magnetic resonance. All compounds were evaluated for antimalarial activity against Plasmodium falciparum (3D7) and for antimycobacterium activity against Mycobacterium tuberculosis H37Ra and Mycobacterium bovis. Compound $\mathbf{8}$ was found to have promising antimalarial activity $\left(\mathrm{IC}_{50} 4.39 \pm 0.25 \mu \mathrm{M}\right)$, promising antimycobacterium activity $\left[\mathrm{IC}_{50} 4.50 \pm 0.75 \mu \mathrm{M}(3.31 \mu \mathrm{g} / \mathrm{mL})\right]$ against M. tuberculosis H37Ra and at $100 \mu \mathrm{g} / \mathrm{mL}$, showed $55.6 \%$ inhibition of M. bovis. Compound 9 showed moderate inhibition of $P$. falciparum growth (35\% inhibition at $10 \mu \mathrm{M}$ ) with respect to the positive control atovaquone and $67.4 \%$ inhibition against $M$. bovis at $100 \mu \mathrm{g} / \mathrm{mL}$ with respect to the positive control rifampicin.

\section{Key words}

Leucas mollissima - Lamiaceae · antimalarial · antimycobacterium $\cdot$ phytochemicals

Supporting information available online at http://www.thieme-connect.de/products

The genus Leucas from the family Lamiaceae comprises about 80 species [1]. In India, 43 species are available [2], of which 21 are found in the state of Maharashtra [3]. Plants of the genus Leucas have been widely employed by traditional healers to cure many disease conditions, which suggests that this genus has potential for the discovery of new drugs or lead molecules [1]. Leucas mollissima Wall. is distributed in India in the western peninsular, subtropical Himalayan region, and in the states of West Bengal and Orissa [4]. The juice from the leaf of this herb is applied externally to treat ailments relating to headache, while the decoction has been used orally to treat diabetes mellitus and liver diseases such as hepatitis [5]. In our continuing efforts to isolate bioactive compounds from plants found in the Western Ghats of Maharashtra for the development of new drugs active against infectious diseases such as malaria and tuberculosis, we report herein the isolation and structure elucidation of compound 1, (-)epi-marmelo lactone, a new natural product, along with eight known compounds (2-9) ( $\bullet$ Fig. 1). Compounds 8 and $\mathbf{9}$ were evaluated for antimalarial activity against Plasmodium falciparum (3D7) and antimycobacterium activity against Mycobacterium tuberculosis H37Ra and Mycobacterium bovis.

Compound 1 was isolated as yellow gum. The molecular formula was determined as $\mathrm{C}_{10} \mathrm{H}_{16} \mathrm{O}_{3}$ from HR-ESI-MS (Fig. 1 S, Supporting Information), which showed a pseudo-molecular peak at $207.0991[\mathrm{M}+\mathrm{Na}]^{+}$indicating three indices of hydrogen deficiency. This was supported by ${ }^{13} \mathrm{C}$ NMR ( Table 1) spectral data. The ${ }^{1} \mathrm{H}$ NMR spectrum ( $\odot$ Table 1 ) showed one singlet methyl at $\delta_{\mathrm{H}}$ 1.35 , one doublet methyl at $\delta_{\mathrm{H}} 1.30(J=7.3 \mathrm{~Hz})$, two methines multiplates at $\delta_{\mathrm{H}} 2.69$ and 4.76 , olefinic methines at $\delta_{\mathrm{H}} 5.94$ (dd, $J=17,10 \mathrm{~Hz})$, and methylene protons at $\delta_{\mathrm{H}} 5.16(\mathrm{~d}, J=10 \mathrm{~Hz})$ and $5.34\left(\mathrm{~d}, J=17 \mathrm{~Hz}\right.$ ). The ${ }^{13} \mathrm{C}$ NMR ( Table 1) and DEPT-135 (Fig. 4S, Supporting Information) spectra showed the presence of two methyls, three methylenes, three methines, and two quaternary carbons. Methylene at $\delta_{\mathrm{H}} 5.16-5.34\left(\delta_{\mathrm{C}} 112.9\right)$ and methine at $\delta_{\mathrm{H}} 5.94\left(\delta_{\mathrm{C}} 143.9\right)$ indicated the presence of a double bond as an olefinic end group, and one quaternary carbon at $\delta_{\mathrm{C}} 179.4$ showed the presence of a lactone carbonyl carbon. These data indicated 1 to be a monocyclic compound belonging to the lactone class. The structure of 1 was assigned by 2D NMR as follows: A proton at $\delta_{\mathrm{H}} 2.69\left(\delta_{\mathrm{C}} 33.8, \mathrm{H}-2\right)$ and protons at $\delta_{\mathrm{H}} 2.11$ and 2.05 $\left(\delta_{\mathrm{C}} 36.5, \mathrm{H}_{2}-3\right)$ showed a heteronuclear multiple bond correlation (HMBC; Fig. 6S, Supporting Information) with a carbonyl at $\delta_{\mathrm{C}}$ $179.4(\mathrm{C}-1)$ indicating that there was a lactone ring with one methine and one methylene. Protons at $\delta_{\mathrm{H}} 1.98$ and $1.80\left(\delta_{\mathrm{C}}\right.$ 46.9, $\mathrm{H}_{2}-5$ ) showed an HMBC correlation with a carbon at $\delta_{\mathrm{C}}$ $75.8\left(\delta_{\mathrm{H}} 4.76, \mathrm{C}-4\right)$ and with a quaternary carbon at $\delta_{\mathrm{C}} 72.6(\mathrm{C}-6)$. Protons at $\delta_{\mathrm{H}} 5.94\left(\delta_{\mathrm{C}} 143.9, \mathrm{H}_{1}-7\right), 5.34$, and $5.16\left(\delta_{\mathrm{C}} 112.9, \mathrm{H}_{2}-8\right)$ showed an HMBC correlation with a carbon at $\delta_{\mathrm{C}} 72.6$ (C-6). Similarly, the proton at $\delta_{\mathrm{H}} 1.35\left(\delta_{\mathrm{C}} 28.7, \mathrm{H}_{3}-10\right)$ showed an HMBC correlation with an unsaturated carbon at $\delta_{\mathrm{C}} 143.9\left(\delta_{\mathrm{H}} 5.94, \mathrm{C}-7\right)$. These observations confirmed the presence of a side chain with an olefinic end group. The key HMBC correlations are shown in - Fig. 2. Correlation spectroscopy (COSY; Fig. 7 S, Supporting Information) correlations observed between $\delta_{\mathrm{H}} 1.30\left(\mathrm{H}_{3}-9\right)$ and $2.69(\mathrm{H}-2), \delta_{\mathrm{H}} 2.69(\mathrm{H}-2)$ and $2.11\left(\mathrm{H}_{2}-3\right), \delta_{\mathrm{H}} 2.11\left(\mathrm{H}_{2}-3\right)$ and $4.76(\mathrm{H}-4)$, and $\delta_{\mathrm{H}} 4.76(\mathrm{H}-4)$ and $1.80-1.98\left(\mathrm{H}_{2}-5\right)$ supported the structure of 1 to be a lactone with a side chain ( Fig. 2 ). The nuclear Overhauser effect spectroscopy (NOESY; Fig. 8S, Supporting Information) correlations observed between $\delta_{\mathrm{H}} 2.69(\mathrm{H}-$ 2 ) and $\delta_{\mathrm{H}} 1.35\left(\mathrm{H}_{3}-10\right), \delta_{\mathrm{H}} 1.30\left(\mathrm{H}_{3}-9\right)$ and $\delta_{\mathrm{H}} 2.11\left(\mathrm{H}_{2}-3\right)$, and $\delta_{\mathrm{H}}$ $1.30\left(\mathrm{H}_{3}-9\right)$ and $\delta_{\mathrm{H}} 4.76(\mathrm{H}-4)$ led us to assign the stereochemistry by placing methyl at the 2 position, $\beta$ orientating, and the side chain at the 4 position, $\alpha$ orientating, relatively ( Fig. 2 ). Compound 1 was found to have a negative specific rotation $\left([\alpha]_{\mathrm{D}}^{26}\right.$ : - 81.90). Thus, 1 was found to be an epimer of the previously isolated and structurally similar marmelo lactone from the fruit of Cydonia oblonga Mill. (Rosaceae) [6], and hence identified as a new natural product, $(2 S, 4 R, 6 S)$-2,6-dimethyl-6 hydroxy-7ene-4-olide, belonging to the class of (-) epi-marmelo lactones. Compound $\mathbf{2}$ was identified as schensianol A by comparing its NMR data from a previously reported article in which it was isolated from Euonymus schensianus Maxim. (Celastraceae) [7]. Compounds $\mathbf{3}$ and $\mathbf{4}$ were identified as vanillin and $\beta$-Hydroxy propiovanillone, respectively, by comparing their NMR data with 


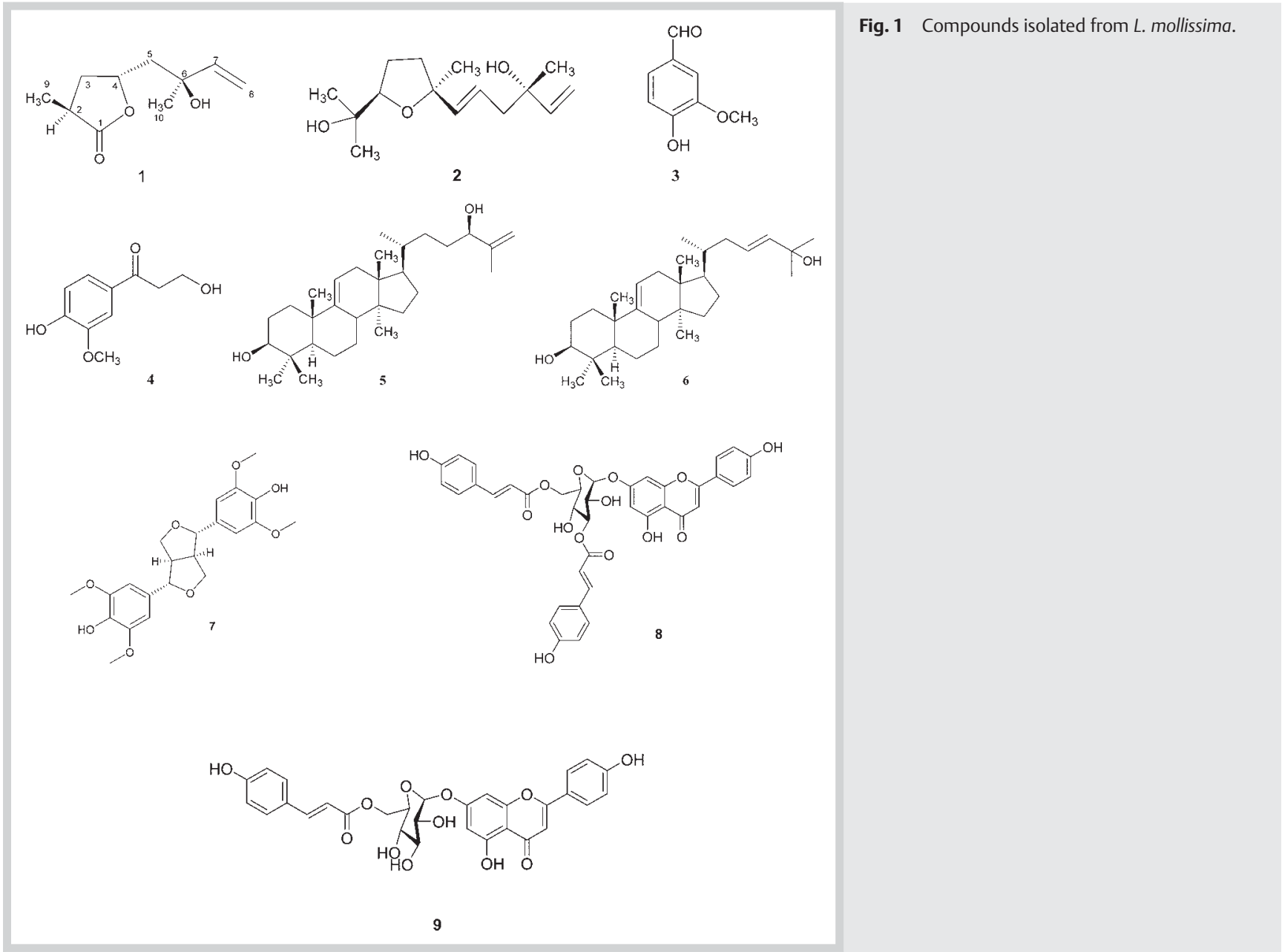

\begin{tabular}{|clll|} 
Carbon & ${ }^{13} \mathbf{C}\left(\delta_{C}\right)$ & ${ }^{1} \mathbf{H}\left(\delta_{H}\right)$ & HMBC \\
\hline 1 & 179.4 & - & $\mathrm{H}_{1}-2, \mathrm{H}_{2}-3$ \\
\hline 2 & 33.8 & $2.69(1 \mathrm{H}, \mathrm{m})$ & $\mathrm{H}_{2}-3, \mathrm{H}_{3}-9$ \\
\hline 3 & 36.5 & $2.05(1 \mathrm{H}, \mathrm{m}), 2.11(1 \mathrm{H}, \mathrm{m})$ & $\mathrm{H}_{3}-9$ \\
\hline 4 & 75.8 & $4.76(1 \mathrm{H}, \mathrm{m})$ & $\mathrm{H}_{2}-5$ \\
\hline 5 & 46.9 & $1.80(1 \mathrm{H}, \mathrm{m}), 1.98(1 \mathrm{H}, \mathrm{m})$ & $\mathrm{H}_{3}-10$ \\
\hline 6 & 72.6 & - & $\mathrm{H}_{2}-5, \mathrm{H}_{3}-10, \mathrm{H}_{1}-7, \mathrm{H}_{2}-8$ \\
\hline 7 & 143.9 & $5.94(1 \mathrm{H}, \mathrm{dd}, J=10,17 \mathrm{~Hz})$ & $\mathrm{H}_{3}-10$ \\
\hline 8 & 112.9 & $5.16(1 \mathrm{H}, \mathrm{d}, J=10 \mathrm{~Hz}), 5.34(1 \mathrm{H}, \mathrm{d}, J=17 \mathrm{~Hz})$ & $\mathrm{H}_{1}-7$ \\
\hline 9 & 15.8 & $1.30(3 \mathrm{H}, \mathrm{d}, J=7.3 \mathrm{~Hz})$ & $\mathrm{H}_{1}-2$ \\
\hline 10 & 28.7 & $1.35(3 \mathrm{H}, \mathrm{s})$ & \\
\hline
\end{tabular}

Table $1{ }^{1} \mathrm{H}$ (chloroform-d, $400 \mathrm{MHz}$ ), ${ }^{13} \mathrm{C}$ NMR (chloroform- $d$, $100 \mathrm{MHz}$ ), and HMBC data of compound 1.

m: multiplate; s: singlet; d: doublet; dd: doublet of doublet

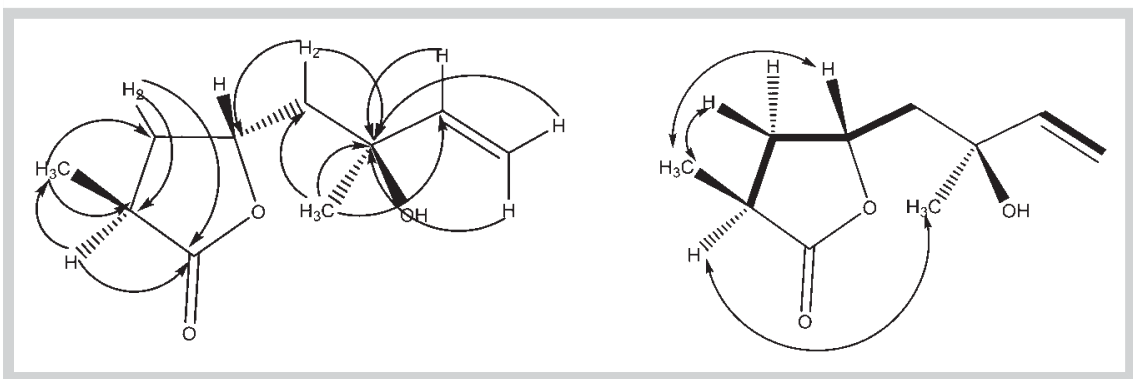

Fig. $2 \operatorname{Key} \operatorname{HMBC}(\rightarrow)$, $\operatorname{NOESY}(\leftrightarrow)$, and $\operatorname{COSY}(-)$ correlations of compound $\mathbf{1}$. 
Table 2 In vitro antimalarial activity of compounds $\mathbf{8}$ and $\mathbf{9 .}$

\begin{tabular}{|llll} 
Compound & $\begin{array}{l}\text { Concentration } \\
(\boldsymbol{\mu M}) \text { or } \\
\left({ }^{*} \boldsymbol{\mu g} / \mathrm{mL}\right)\end{array}$ & $\begin{array}{l}\text { Average \% growth } \\
\text { inhibition }(\mathbf{n}=3) \\
( \pm \text { standard } \\
\text { deviation) }\end{array}$ & $\mathrm{IC} 5(\mu \mathrm{M})$ \\
\hline $\mathbf{8}$ & 10 & $102.2 \pm 1.11$ & $4.39 \pm 0.25$ \\
\hline $\mathbf{9}$ & 10 & $35.29 \pm 7.95$ & $\mathrm{ND}$ \\
\hline LMM & $1^{*}$ & $32.24 \pm 3.62$ & $\mathrm{ND}$ \\
\hline ATQ & 1 & $100 \pm 4.59$ & 0.0082 \\
\hline
\end{tabular}

ATQ = atovaquone (standard antimalarial compound); ND = not determined

those available in the literature $[8,9]$. Compound 5 was identified as a lanost-9(11),25-diene-3 $3,24 \beta$-diol and compound 6 was identified to be a lanost-9(11),23E(24)-diene-3 $\beta, 25$-diol by comparison of literature NMR data and mass spectra reported for compounds isolated from Mulgedium tataricum (L.) DC. (Asteraceae) $[10,11]$. Compound 7 was identified as (+) syringaresinol by comparing its NMR data with those available in the literature [12]. Compound 8 was identified as apigenin $7-0-\beta-\mathrm{D}\left(-3^{\prime \prime}, 6^{\prime \prime}-\mathrm{p}-\right.$ E-dicoumaroyl)-glucoside, Anisofolin A, by comparing its spectral data with those available in literature [13-15]. Compound 9 was identified as apigenin 7-O- $\beta$-D-(-6"-p-E-coumaroyl)-glucoside by comparing its spectral data with the literature $[16,17]$.

\section{Material and Methods}

$\nabla$

General experimental procedures, chemicals, and biochemicals: Optical rotations were measured using a JASCO P-1020 polarimeter. The ${ }^{1} \mathrm{H}$ and ${ }^{13} \mathrm{C}$ NMR spectra were recorded on a Bruker Avance III Ultra Shield NMR instrument (proton operating field strength: $400 \mathrm{MHz}$ ) at $25^{\circ} \mathrm{C}$. LC-ESI-MS was recorded with a Waters Acquity LC-MS instrument. HR-ESI-MS using an Autoconcept mass spectrometer. Column chromatography was performed using silica gel, mesh 230-400 (Thomas Baker, Ltd.), and preparative thin-layer chromatography plates supplied by Merck Ltd. A Spectramax Plus 384 plate reader was used. Rifampicin and MTT were purchased from Sigma-Aldrich. Britelite plus reagent was purchased from Perkin Elmer. M. tuberculosis H37Ra (ATCC 25177) was obtained from MTCC, Chandigarh, India. M. bovis (ATCC 35745 ) was obtained from AstraZeneca, Bangalore, India. SybrGreen I nucleic acid stain was purchased from Life Technologies.

Plant material: L. mollissima, were collected from the mulshi area of Western Ghats, Pune, India on January, 2012 in full flowering season, shade dried, and pulverized. A herbarium voucher of this plant has been deposited in the Botanical Survey of India, Western Circle, Pune (Deposition No. SPJ-4).

Extraction and isolation: Pulverized aerial parts $(1.09 \mathrm{~kg})$ were extracted with acetone $(3 \mathrm{~L} \times 3 \times 14 \mathrm{~h})$ at room temperature. The acetone solubles were filtered and concentrated under reduced pressure to yield a greenish acetone extract, LMA (13.6 g, 1.24\% based on dry weight of plant). The residual plant material was extracted with methanol $(3 \mathrm{~L} \times 3 \times 14 \mathrm{~h})$ at room temperature. The methanol solubles were filtered and concentrated under reduced pressure to yield a brownish methanol extract, LMM (47.5 g, $4.35 \%$, based on dry weight of plant). The isolation of compounds 1-6 from the acetone extract and 7-9 from the methanol extract is provided in Supporting Information. (-)epi-marmelo lactone (1): Gum; $[\alpha]_{\mathrm{D}}^{26}$ : -81.90 ( c $0.3 \%$ in $\mathrm{CHCl}_{3}$ ); ${ }^{1} \mathrm{H}$ NMR (chloroform- $d, 400 \mathrm{MHz}$ ) $\delta_{\mathrm{H}}$ and ${ }^{13} \mathrm{C}$ NMR (chloroform- $d$, $100 \mathrm{MHz}) \delta \mathrm{c}$ are shown in $\odot$ Table 1 ; HR-ESI-MS: $m / z[\mathrm{M}+\mathrm{Na}]^{+}$ 207.0991 (calculated for $\mathrm{C}_{10} \mathrm{H}_{16} \mathrm{O}_{3}, 184.23$ ).

Biological screenings: Antimalarial screening: A primary screening for compounds 1-9 was done as per standard protocols [18] at the $10 \mu \mathrm{M}$ concentration, and for the crude mixture, a $1 \mu \mathrm{g} / \mathrm{mL}$ concentration was used. Protocol details are given in Supporting Information. Compound $\mathbf{8}$ was found to have significant antimalarial activity and was capable of completely inhibiting parasite growth at the $10 \mu \mathrm{M}$ concentration. The $\mathrm{IC}_{50}$ was found to be $4.39 \pm 0.25 \mu \mathrm{M}$ compared to the positive control atovaquone, as shown in 0 Table 2 . However, compound $\mathbf{9}$ had only a moderate effect on parasite growth.

Antimycobacterial screening: Compounds 1-9 were evaluated for their in vitro inhibition effect against $M$. tuberculosis H37Ra (ATCC No.25177) using the XTT Reduction Menadione Assay protocol and M. bovis (ATCC No. 35745) using the Nitrate Reductase assay protocol [19-21]. Protocol details are given in Supporting Information. Compound $\mathbf{8}$ was found to be active with an $\mathrm{IC}_{50}$ of $4.50 \pm 0.75 \mu \mathrm{M}(3.31 \mu \mathrm{g} / \mathrm{mL})$ against $M$. tuberculosis $\mathrm{H} 37 \mathrm{Ra}$ compared to the positive control rifampicin, with an $\mathrm{IC}_{50}$ of $0.0019 \pm 0.0003 \mu \mathrm{g} / \mathrm{mL}$. Compounds 8 and 9 at the $100 \mu \mathrm{g} / \mathrm{mL}$ concentration showed growth inhibition of $55.6 \%$ and $67.4 \%$, respectively, against $M$. bovis.

\section{Supporting information}

HR-ESI-MS, ${ }^{1} \mathrm{H},{ }^{13} \mathrm{C}$, DEPT, and 2D NMR data of compound 1, the dose-response curve for compound $\mathbf{8}$, isolation of compounds $\mathbf{1 -}$ 9, and biological screening protocols and NMR and other characterization data for compounds $\mathbf{2 - 9}$ are available as Supporting Information.

\section{Acknowledgements \\ $\nabla$}

We wish to thank Dr. P. Tetali, NGCPR, Shirwal, Satara, for identifying the plant material and Dr. Shanthakumari of the CSIR-NCL, Pune for HR-ESI-MS analysis. The Academic Council of Scientific and Innovative Research, New Delhi, India is acknowledged for financial support.

\section{Conflict of Interest}

$\nabla$

The authors declare no conflict of interest.

\section{References}

1 Chouhan HS, Singh SK. A review of plants of genus Leucas. J Pharmacogn Phytother 2011; 3: 13-26

2 Khanam M, Hassan MA. A critical study of the genus Leucas R. Br. (Lamiaceae) from Bangladesh. Bangl J Plant Taxon 2005; 12: 1-10

3 Singh NP, Lakshminarasimhan P, Karthikeyan S, Prasanna PV. Flora of Maharashtra State. Calcutta: Botanical Survey of India; 2001: 734

4 Thacker MS, Lala SR, Krishnan MS, Prashad B, Chopra RN, Santapau H, Sastri BN. The wealth of India, raw materials, Vol. VI. New Delhi: CSIR; 1962: 80

5 Das SN, Patro VJ, Dinda SC. A review: Ethnobotanical survey of genus Leucas. Pharmacogn Rev 2012; 6: 100-106

6 Nishida Y, Konno M, Fukushima Y, Ohrui H, Meguro H. ${ }^{13}$ C-NMR Studies on Marmelo Lactones and Related 2, 4-di Alkylated $\gamma$-lactones. Agric Biol Chem 1986; 50: 191-193

7 Zheng XK, Guo JH, Feng WS, Li HW. Three new sesquiterpenes from Euonymus schensianus Maxim. Chinese Chem Lett 2009; 20: 952-954

8 Mukonyi KW, Ndiege IO. 2-Hydroxy-4-methoxybenzaldehyde: aromatic taste modifying compound from Mondia whytei skeels. Bull Chem Soc Ethiop 2001; 15: 137-141 
9 Lou JR, Jiang HE, Zhao YX, Zhao J, Qian JF. Components of the heartwood of from an ancient tomb. Chem Nat Compd 2008; 44: 6-9

10 Wang XX, Jia ZJ. Two new lanostane-type triterpenoids from Mulgedium tataricum. Chinese Chem Lett 2006; 17: 204-206

11 Wang XX, Lin CJ, Jia ZJ. Triterpenoids and sesquiterpenes from Mulgedium tataricum. Planta Med 2006; 72: 764-767

12 Park HB, Lee KH, Kim KH, Lee IK, Noh HJ, Choe SU, Lee KR. Lignans from the root of Berberis amurensis. Nat Prod Sci 2009; 15: 17-21

13 Miyaichi Y, Segawa A, Tomimori T. Studies on Nepalese crude drugs. XXIX. Chemical constituents of Dronapuspi, the whole herb of Leucas cephalotes Spreng. Chem Pharm Bull (Tokyo) 2006; 54: 1370-1379

14 Rao LJM, Kumari GNK, Rao NSP. Anisofolin-A, a new acylated flavone glucoside from Anisomeles ovata R. Br. Heterocycles 1982; 19: 16551661

15 Karioti A, Protopappa A, Megoulas N, Skaltsa H. Identification of tyrosinase inhibitors from Marrubium velutinum and Marrubium cylleneum. Bioorg Med Chem 2007; 15: 2708-2714

16 Delazar A, Celik S, Gokturk RS, Unal O, Nahar L, Sarker SD. Two acylated flavonoid glycosides from Stachys bombycina, and their free radical scavenging activity. Pharmazie 2005; 60: 878-880

$17 \mathrm{Ku} C T$, Chen SC, Wang JP, Wu JB, Kuo SC. Studies on anti-inflammatory constituents of Leucas Mollissima WALL. var. Chinensis Benth. Chin Pharm J 2000; 52: 261-273

18 Radfar A, Mendez D, Moneriz C, Linares M, Marin-Garcia P, Puyet A, Diez A, Bautista JM. Synchronous culture of Plasmodium falciparum at high parasitemia levels. Nat Protoc 2009; 4: 1899-1915

19 Dzoyem JP, Guru SK, Pieme CA, Kuete V, Sharma A, Khan IA, Saxena AK, Vishwakarma RA. Cytotoxic and antimicrobial activity of selected Cameroonian edible plants. BMC Complement Altern Med 2013; 13: 7883
20 Singh U, Sarkar D. A novel screening method based on menadione mediated rapid reduction of tetrazolium salt for testing of anti-mycobacterial agents. J Microbiol Meth 2011; 84: 202-207

21 Khan A, Sarkar D. A simple whole cell based high throughput screening protocol using Mycobacterium bovis BCG for inhibitors against dormant and active tubercle bacilli. J Microbiol Meth 2008; 73: 62-68

received February 27, 2015

revised June 30,2015

accepted July 9,2015

\section{Bibliography}

DOI http://dx.doi.org/10.1055/s-0035-1557830

Planta Med Lett 2015; 2: e35-e38

(c) Georg Thieme Verlag KG Stuttgart · New York .

ISSN 2199-157X

\section{Correspondence \\ Dr. Swati P. Joshi}

Division of Organic Chemistry

CSIR-National Chemical Laboratory

Dr. Homi Bhabha Road

Pune 411008, Maharashtra

India

Phone: + 912025902327

Fax: + 912025902629

swatijoshincl@gmail.com

\section{License terms}

() (1) $\Theta \circledast$ 